\title{
Effect of Sodium Carbonate and Bicarbonate Contamination on the Rheological Properties of Water Based Mud
}

\author{
Hisham Ben Mahmud ${ }^{1, a, *}$, Walid Mohamed Mahmud², Rugen Ayanarappan ${ }^{1}$, and Saber Elmabrouk ${ }^{3}$

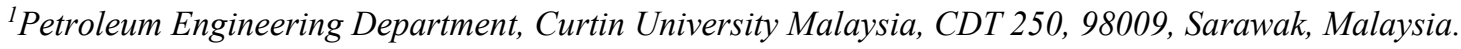 \\ ${ }^{2}$ Petroleum Engineering Department, University of Tripoli, Libya. \\ ${ }^{3}$ Libyan Academy, Janzour, Libya. \\ ${ }^{a}$ https://orcid.org/0000-0002-8231-9730
}

\begin{abstract}
Stability of drilling fluid property is very crucial for smooth and less troublesome drilling because contamination of drilling fluid during drilling operations is usually unavoidable. This work presents an investigation of the effects of various contaminants on laboratory prepared water based drilling mud at ambient conditions. Three mud samples each has a different concentrations of Sodium Carbonate $\left(\mathrm{Na}_{2} \mathrm{CO}_{3}\right)$ and Sodium Bicarbonate $\left(\mathrm{NaHCO}_{3}\right)$ contaminants were mixed with Water Based Mud (WBM) fluid and formulated to investigate their effect on drilling fluid rheological properties. The measured properties were $\mathrm{pH}$, fluid loss, mud thickness, plastic viscosity and yield point. The results indicate that the mud thickness increased with the increase of different cement contaminations. Mud $\mathrm{pH}$ increased as sodium carbonate concentration increased but decreased as bicarbonate concentration increased. Plastic viscosity decreased with the increase of concentrations of both cement contamination and the treating agent while yield point increased with the increase of cement contamination concentration. Furthermore, fluid loss was found to proportionally increase with the increase of contaminants concentration. Most of the results obtained from this work are consistent with previously published results; however, the developed mud rheological properties should be further studied at elevated temperature and pressure conditions encountered while drilling an oil or gas well.
\end{abstract}

Keywords: WBM, Contaminants (Sodium Carbonate, Sodium Bicarbonate), Treating agents (calcium sulphate, Sodium Hydroxide), Rheological properties, Ambient condition

\section{INTRODUCTION}

Circulating mud while drilling an oil or gas well is the main task of the circulating system. Therefore, the drilling mud properties, especially the rheological properties, should be given extensive attention as they describe the mud characteristics at various flow conditions. Various flow conditions occur during drilling because of shear rate, shear stress and the type of mud contaminants. However, contaminants, such as acid gaseous, encountered during drilling are usually unavoidable and may significantly affect the rheological properties of the drilling mud that must be maintained throughout the drilling operation. Thus, any rheological properties alterations are a sign that the mud has become contaminated. If mud contamination is not instantly treated, low rate in penetration, abnormal pressure and pipe sticking are among the complications that could occur during the drilling operation. Adding additives into the mud while mud is being re-fed through the drill stem usually treats the contaminated mud. It is not achievable, however, that the mud is fully restored but the additives can minimize contaminants' concentrations and thereof their negative effects. Mud additives are chemicals added into the drilling mud to enhance its performance by altering its compositions and properties in order to eliminate or minimize the effects of contaminants. Once, the rheological properties of the mud and the ideal composition has been established, several crucial functions are performed by the mud that include lubricating and cooling the drill bit, equalizing wellbore pressure, transporting drill cuttings to the surface, maintain wellbore stability and suspending particles when the drilling operation stops. Cost, type of well, environmental impact and performance are important factors that dictate the type of drilling mud that must be used as mud can be of gas, gas/liquid mixture or liquid nature. The liquid, which is most commonly used, can be oilbased muds, OBM, or water-based muds, WBM, indicating that the continuous phase of the mud system is either oil or water, respectively. However, among many factors such as maintaining the original wettability status of the target formation(s), WBM are predominantly used in the petroleum industry. Air also has been used as a drilling mud but because of air's density and compressibility, it may not always prevent the wellbore from collapsing.

Contaminants are material or substances that change mud properties in an undesirable manner. While drilling an oil or gas well, drill cuttings and solid rock particles that result from the drilling operation is the most encountered drilling mud contaminant that cause significant decrease in the rate of drilling penetration. Chemical contents of penetrated formations are also contaminants that may destroy the rheological properties of the designed mud when both the chemicals and mud come in contact with each other. Salt contamination in drilling mud is considered as naturally occurring contaminant that maybe initiated from various sources including salty water content in drilling mud and 
drilling through salt formation. Salt contamination can be identified in the drilling mud as the chloride concentration, fluid loss, and yield point increase and both alkalinities and $\mathrm{pH}$ decrease. However, only if freshwater is contaminated while drilling through a salt formation is considered drilling mud contamination. Salt contaminants that may ruin the drilling mud include potassium chloride, $\mathrm{KCl}$, sodium chloride, $\mathrm{NaCl}$, magnesium chloride, $\mathrm{MgCl}_{2}$ and calcium chloride, $\mathrm{CaCl}_{2}$. Calcium and magnesium ions in seawater make seawater another major source for salt contamination in the drilling mud. Calcium and magnesium ions are insoluble in WBM and caustic soda additive, or any other additive, and must be mixed in the mud in order to precipice the calcium and magnesium ions. Salt contaminants effects on the efficiency of drilling mud has been previously studied by setting the gel strength, plastic viscosity and yield point as the main parameters affected by the salt contaminants in seawater [1]. It was found that the rheological properties of the contaminated mud gradually increased in comparison to blank or un-ruined mud. However, the reported results were based on one seawater concentration without specifying the exact values of the magnesium and calcium ions.

Contamination of drilling mud by natural acid gases, often encountered in underground formations, such as hydrogen sulfide, $\mathrm{H}_{2} \mathrm{~S}$, and carbon dioxide, $\mathrm{CO}_{2}$, is also common. WBM is usually utilized to safely drill through formations that contain these gases so that the mud hydrostatic pressure is higher than the pore pressure. However, once in contact with WBM, hydrogen sulfide and carbon dioxide gases cause clays to form clumps that may cause the drill pipe to loss its ductility and brittle. Carbon dioxide leakage from the formation to the wellbore during drilling may also cause carbonate/bicarbonate contamination because hydroxide ion in alkaline mud reacts with carbon dioxide and cause soluble carbonate/bicarbonate accumulation. Mud gel strength may also increase if additives, such as sodium bicarbonate, are excessively added to mud because it also causes carbonate/bicarbonate contamination.

Another form of contamination is clay flocculation, which usually occurs while removing excess or remaining cement from the wellbore. This form of contamination is referred to as cement contamination and detected by the increase of mud $\mathrm{pH}$, viscosity and hardness. Introducing additives such as sodium bicarbonate and soda ash to the drilling mud normally treats cement contamination, up to a certain range. However, these additives cannot treat the drilling mud if the mud is severely contaminated by cement then introducing freshwater mud into the contaminated mud becomes necessary. Based on one cement concentration, drilling mud properties including hardness, viscosity and $\mathrm{pH}$ were experimentally shown to increase as the mud becomes contaminated by cement but mud density was unaffected by cement contamination [2].

Regular continuous checks and rheological tests are normally conducted on the drilling mud throughout the drilling process in order to early detect any contaminants in the mud and the required additives for treatment so that mud effectiveness is maintained. Mud density is among the most important properties that are regularly checked to avoid significant problems while drilling. A suitably high mud density prevents the wellbore from caving and increases mud buoyancy so that drill cuttings can be carried to the surface. Barite is normally added as weighting material to appropriately increase contaminated mud density because excessive increase in mud density leads to low rate of penetration, higher pump rate, lost circulation and thickening of mud cake. It was found experimentally that the density is inversely proportional to the penetration rate, i.e. as the mud density increased the rate of penetration decreased [3].

Plastic viscosity is another important drilling mud property that is constantly measured while drilling, as it is a measure of the internal resistance of a fluid to flow drill cuttings and solid particles. Quantity of solid particles in the mud and mud viscosity control the plastic viscosity that can be minimized in order to decrease high shear rate viscosity [2]. High plastic viscosity of mud might reduce rate of penetration and increase pressure drop in the hole, however, high plastic viscosity mud provides better hole cleaning. Overall, lowering or minimizing the drilling mud plastic viscosity is safer [4]. It was also found experimentally that cement contamination severely affected the plastic viscosity in comparison with other contaminants [5].

Attractive forces between the particles in drilling mud are measured by the yield point, which increases as the larger molecular bond between mud molecules increases. High resistance to flow is created from collision between larger molecular bond particles in drilling mud and thereof higher viscosity. High yield point in drilling mud occurs as contaminants and additives in large amount coexist in drilling mud, however, yield point maybe reduced by increasing the shear rate of the drilling mud that reduces the interaction rate between molecules. Experimental work was made on various concentrations of the bentonite contaminant to study its effect on drilling mud yield point [4]. It was found that high molecular bond between particles in the drilling mud increases with the increase of bentonite concentration, which leads to an increase in the mud yield point. As drilling mud circulation pauses, during the drilling operation, gel strength is the key mud property that enables the mud to suspend drill cuttings. Usually 2 to $4 \mathrm{lb} / 100 \mathrm{ft}^{2}$ gel strength is required in order to suspend drill cuttings in the mud or otherwise drill cuttings accumulate in the bottom of the hole [2].

The aims of this work are to study and identify contaminants that may commingle with drilling mud and their effects on the rheological properties of the mud. The aim also includes finding the appropriate additives and required quantities in order to treat the affected or contaminated mud as adding inaccurate amounts of additives may cause unwanted changes in the mud rheological properties. Thus, laboratory experiments were conducted on two miscellaneous types and concentrations of contaminants and their rheological properties were measured. By comparing the rheological properties of the affected mud with the base mud, the effects of contaminants on WBM were determined.

\section{METHODOLOGY AND EXPERIMENTAL SETUP}

Figure 1 shows the sensitive electronic weighing balance that was used for the experiments to weigh substances at scale uncertainty of only $0.01 \mathrm{~g}$. The equipment used to measure 
densities, pound per gallon (ppg), of base and contaminated muds is the mud balance shown in Figure 2.

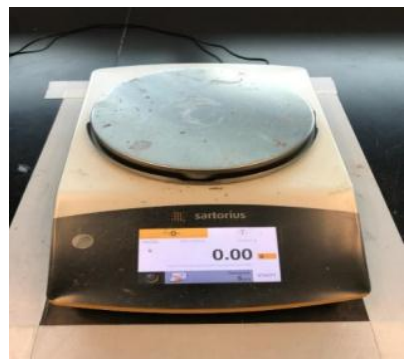

Figure 1: The sensitive electronic weighing balance

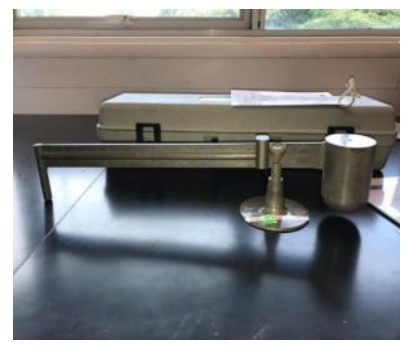

Figure 2: Mud density balance in pound per gallon (ppg).
Figure 3 shows the Hamilton mud mixer used to mix substances required to formulate drilling mud. Mud was stirred prior to each experimental run in the mud mixer for 10 minutes. Figure 4 shows the 6-speed Fann viscometer used to measure mud viscosity, in $\mathrm{cP}$, at different speed. Mud viscosity measurements were used to mathematically calculate yield point, get strength and apparent and plastic viscosities. Figure 5 shows the API filter press used to measure mud filter loss and mud cake thickness.

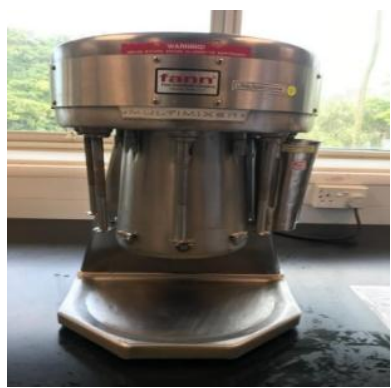

Figure 3: Hamilton mud mixer used to stir mud before each experiment.

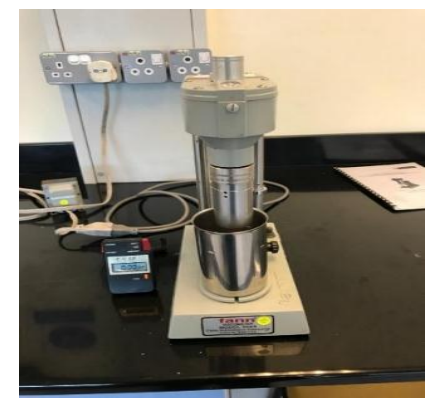

Figure 3: 6-speed Fann viscometer to measure mud viscosity in $\mathrm{cP}$.
The composition of WBM used without contaminant is $350 \mathrm{ml}$ water and $15 \mathrm{~g}$ bentonite. The $350 \mathrm{ml}$ of distilled water was placed into Hamilton mixing cup and the cup was placed in the Hamilton Beach mixer. The electronic weighing balance was then used to weigh $15 \mathrm{~g}$ of bentonite that was gently added into the Hamilton mixing cup at stirring condition for 15 minutes.

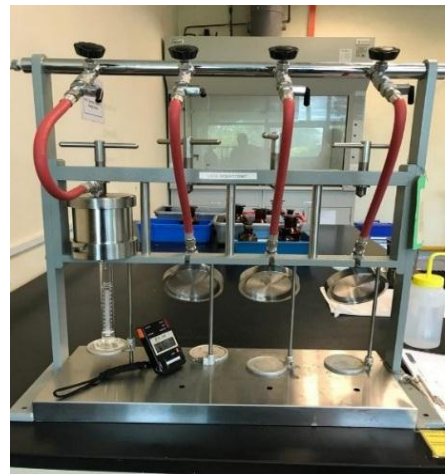

Figure 4: API filter press to measure mud filter loss and thickness of mud cake
In order to measure the drilling mud density, the equipment was first calibrated using freshwater. The cup was fully filled with the mud and sealed by the lid. Excessive mud exiting through the vent hole was removed and cleaned. The balance arm was then placed on the base with the knife-edges on the fulcrum rest. The rider was adjusted until the bubble level stabilizes in the centerline. The mud density was then recorded. In order to measure $\mathrm{pH}$, mud was placed in a $50 \mathrm{ml}$ beaker and stirred using glass rod for 1 minute. The $\mathrm{pH}$ meter cell was then submersed into the $50 \mathrm{ml}$ beaker and as the reading stabilized, the data was recorded.

Solid content measurement was made by first placing the mud in a sand content tube then water was added into the sand content tube and shaken violently for 1 minute. The mixture was then poured into the screen as clear water was filled in the sand content tube and poured into the same screen to ensure all the solid particles rinsed out from the tube. The screen was fitted into funnel upside down. The tip of the funnel was placed into the sand content tube. Clear water was then used to rinse the back of the screen and solid particles accumulated in the sand content tube. Volume percent of solid particles was recorded after solid particles settled in the sand content tube.

The viscometer was used to measure the mud viscosity which then used to calculate the yield point, plastic viscosity and gel strength. Mud was first placed into the test under the rotor sleeve as the pin seated tightly on the base. The leg lock nut was then loosened and the filled test was pushed upwards until the rotor sleeves submersed to the scribed line. The leg lock nut was then tightened. The motor was switched on and the knob on top of the rheometer was adjusted according to the different RPM values. Fluid viscosities at 300 RPM and 600 RPM were recorded.

Equation (1) is used to calculate the mud plastic viscosity:

$$
\begin{aligned}
& \text { Plastic Viscosity }(c p)=\mu_{p}= \\
& 600 \text { RPM reading }-300 \text { RPM reading }
\end{aligned}
$$

$$
\mu_{p}=\theta_{600}-\theta_{300}
$$

Equation 2 is used to calculate the mud yield point:

$$
\begin{aligned}
& \text { Yield Point }\left(\frac{l b}{100} f t^{2}\right)=Y . P= \\
& 300 \text { RPM reading }- \text { Plastic Viscosity }
\end{aligned}
$$

Gel strength was calculated by repeating the same procedure used to calculate the mud viscosity, however, the mud was stirred at 600 RPM for 10 seconds then rested for 10 seconds. The switch was then flipped to low speed and the knob was adjusted to 3 RPM. The maximum deflection of the dial was recorded. The same steps were repeated but at time interval of 10 minutes instead of 10 seconds. Mud filter loss and mud cake thickness were measured as follows:

$\mathrm{T}$-screw in the frame was loosened in order to remove filter cell and then a rubber gasket was placed evenly in base cap and the screen was placed on top of the base cap. A piece of filter paper was placed on the screen and second rubber gasket was placed on top of the filter paper. The third rubber gasket was placed into the top cap. Mud was poured into the filter cell within 1 inch of the top and the top cap was placed on the filter cell. The filter cell with the top cap is placed into the frame and T-screw 
was tightened hardly and securely. A measuring cylinder was placed under the filtrate tube and the pressure relief valve was closed and rotating the regulator valve clockwise set at $100 \mathrm{psi}$ pressure. As the valve in frame open by rotating anticlockwise the time starts immediately. The test was run for 30 minutes and the volume of filtrate was recorded from time to time. After 30 minutes, rotating anticlockwise closed the regulator valve and pressure relief valve was opened gently until all the pressure released then the valve in the frame was closed by rotating it clockwise. The filter cell was removed from the frame by loosening the T-screw and the top cap of the filter cell was removed and the mud inside the filter cell was poured into a mud container. The filter paper was gently removed from the base cap and mud cake thickness was measured using 1/32 inch ruler and other mud properties were recorded. API cell parts were washed and reassembled.

Five different contaminants were used in the experiments that were divided or distributed in three different concentrations so that a total of fifteen contaminated muds were prepared for the experiments as shown in Table 1.

Table 1: Composition of WBM with contaminants

\begin{tabular}{lll}
\hline $\begin{array}{l}\text { Contaminated by } \\
\text { Sodium Carbonate } \\
\left(\mathrm{Na}_{2} \mathrm{CO}_{3}\right)\end{array}$ & Water & $350 \mathrm{ml}$ \\
& Bentonite & $15 \mathrm{~g}$ \\
& $\begin{array}{l}\text { Sodium } \\
\text { Carbonate }\end{array}$ & $1 \mathrm{~g}, 3 \mathrm{~g}, 5 \mathrm{~g}$ \\
\hline $\begin{array}{l}\text { Contaminated by } \\
\text { Sodium Bicarbonate }\end{array}$ & Water & $350 \mathrm{ml}$ \\
$\left(\mathrm{NahCO}_{3}\right)$ & Bentonite & $15 \mathrm{~g}$ \\
& $\begin{array}{l}\text { Sodium } \\
\text { Bicarbonate }\end{array}$ & $1 \mathrm{~g}, 3 \mathrm{~g}, 5 \mathrm{~g}$ \\
\hline
\end{tabular}

In order to formulate WBM with a contaminant, $350 \mathrm{ml}$ of distilled water was placed into Hamilton mixing cup which then was placed in the Hamilton Beach mixer. $15 \mathrm{~g}$ of bentonite and
$1 \mathrm{~g}$ of anhydrite were weighed using the electronic weighing balance. The $15 \mathrm{~g}$ of bentonite was first added into Hamilton mixing cup under stirring condition then followed by the $1 \mathrm{~g}$ of anhydrite and the mixture was stirred for 15 minutes. The same steps were repeated for the 3 and $5 \mathrm{~g}$ of anhydrite the four other contaminants; sodium hydroxide, sodium carbonate, sodium bicarbonate and sand until a total of fifteen contaminated mud samples were prepared.

\section{RESULTS AND DISCUSSION}

\section{Mud thickness}

Figure 6 illustrates the obtained results of mud thickness experiments performed on all formulated mud samples contaminated by 1,3 , and $5 \mathrm{~g}$ of additives, respectively. From the figure, the thickness of mud samples increased with all additives compared to the base mud. Mud thickness of the base mud sample was initially recorded at 2 inch then increased to 2.5 inch with sodium bicarbonate, then 3 inch with sodium carbonate. This increase in mud thickness is due to extra amount of fine particles that are contributed by the cement in WBM. The figure also shows that the mud thickness increased with different contaminations. The mud thickness increased to 3 inch with sodium bicarbonate, 4 inch with sodium carbonate, 6 inch with calcium sulphate and 6 inch with sodium hydroxide. The same trend was noticed in Figure 6 as a $5 \mathrm{~g}$ of contaminant was added in which recorded values of mud thickness became high at 4 inch with sodium bicarbonate, 8 inch with sodium carbonate, 8 inch with calcium sulphate and 7 inch with sodium hydroxide. However, results obtained indicate that adding sodium bicarbonate and carbonate, calcium sulphate, and sodium hydroxide salt increased the base mud thickness and that could be due to the gradual hydration of cement particles that may lead to extreme fluid losses which will result in a high thickness of mud cake [6]. This can lead to decline in the drilling mud performance and cause pipe sticking and excessive formation damage.

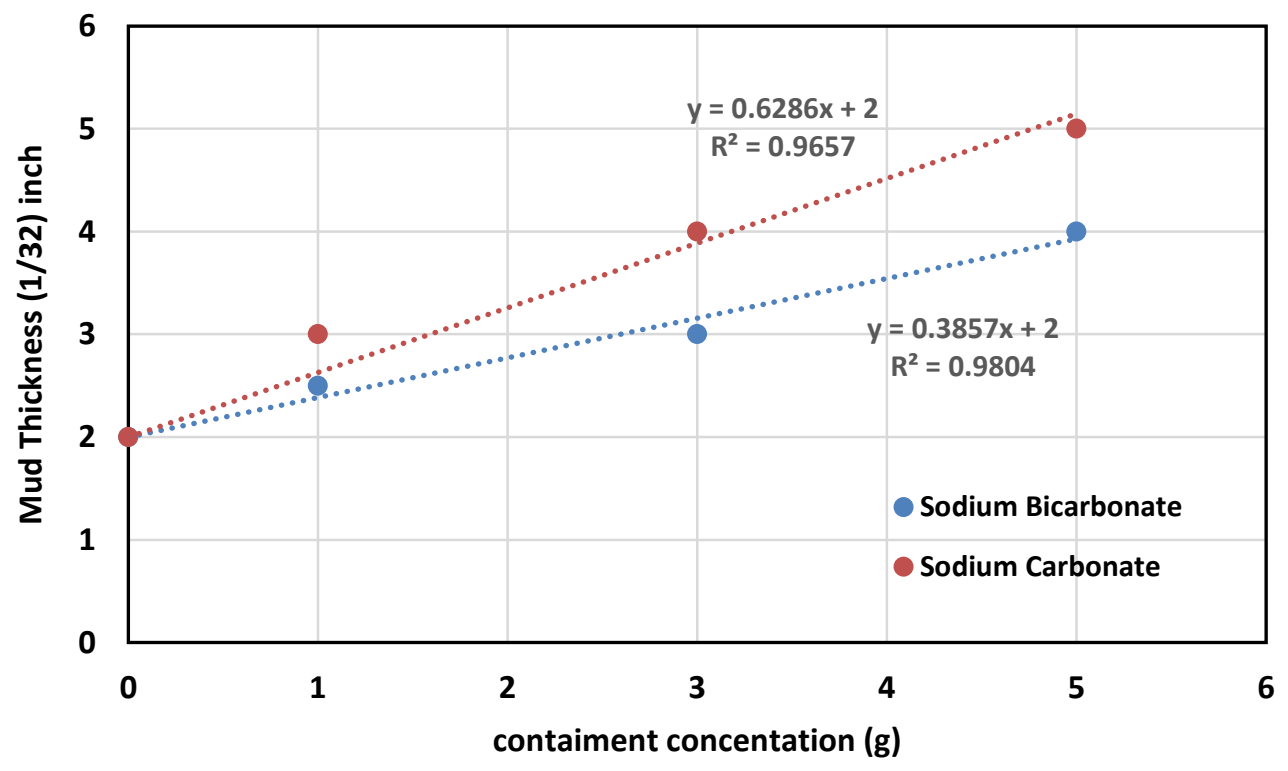

Figure 6: Thickness of WBM different contamination concentration 


\section{Filtrate residue and $\mathrm{pH}$}

Drilling mud $\mathrm{pH}$ is one of the significant elements in corrosion control and it also affects the reaction equilibrium that influences the drilling fluids chemical structure and properties [7]. Figure 6 shows the effect of mud system contaminated by different salts, sodium carbonate and sodium bicarbonate before and after filtration on $\mathrm{pH}$ value at $25^{\circ} \mathrm{C}$. The results indicate that the mud $\mathrm{pH}$ and filtrate residue gradually increased after adding $1 \mathrm{~g}$ of sodium carbonate containment. Then as the concentration of sodium carbonate increased, it steadily affected the mud $\mathrm{pH}$. Therefore, as the concentration of sodium carbonate increased, the mud $\mathrm{pH}$ increased which alternates the mud $\mathrm{pH}$ to alkaline. On the other hand, sodium bicarbonate has a similar trend but at a lower $\mathrm{pH}$ value that is around 8 and causing mud system to be strong base. Thus, the mud solution $\mathrm{pH}$ turns out to be basic due to the presence of additional $\mathrm{OH}^{-}$ions produced by hydrolysis.

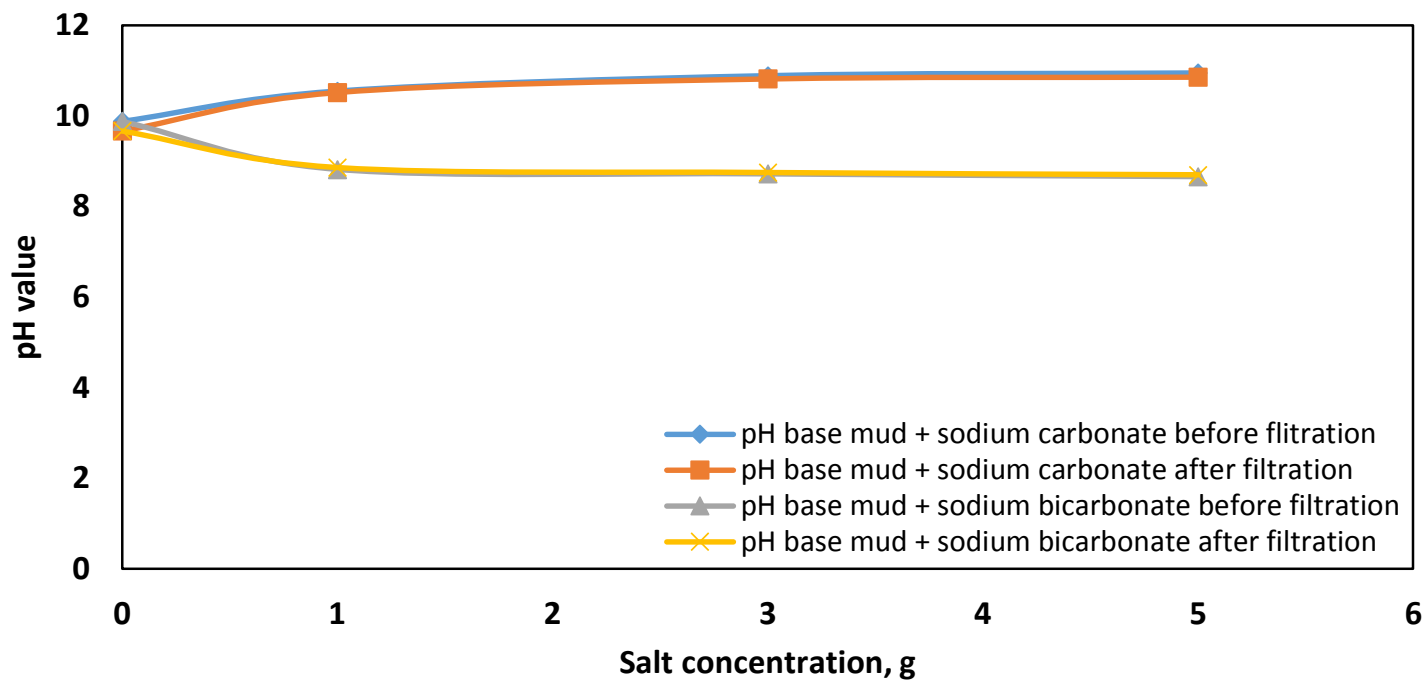

Figure 6: $\mathrm{pH}$ value of $\mathrm{BM}$ with Sodium Carbonate and Biocarbonate

\section{Contaminated mud $\mathrm{pH}$ after treated with additives}

In this section contaminated drilling mud with sodium carbonate and bicarbonate was treated with calcium sulphate to decrease solution $\mathrm{pH}$ and plastic viscosity. Sodium hydroxide and water were added to increase solution $\mathrm{pH}$, decrease density, improve plastic viscosity and dilute the solution. Table 2 lists treated samples composition of sodium carbonate and bicarbonate.

Table 2: Sample name and treated mud composition

\begin{tabular}{|l|l|}
\hline $\begin{array}{l}\text { Sample } \\
\text { Name }\end{array}$ & Mud treatment \\
\hline Sample A & Base Mud $+1 \mathrm{~g} \mathrm{Na}_{2} \mathrm{CO}_{3}$ \\
\hline Sample B & Base Mud $+3 \mathrm{~g} \mathrm{Na}_{2} \mathrm{CO}_{3}$ \\
\hline Sample C & Base Mud + 5g Na $\mathrm{gO}_{3}$ \\
\hline Sample D & Base Mud + $1 \mathrm{~g} \mathrm{Na}_{2} \mathrm{CO}_{3}+1 \mathrm{~g} \mathrm{CaSO}_{4}$ \\
\hline Sample E & $\begin{array}{l}\text { Base Mud }+3 \mathrm{~g} \mathrm{Na}_{2} \mathrm{CO}_{3}+2 \mathrm{~g} \mathrm{CaSO}_{4}+5 \mathrm{~g} \\
\text { Barite }\end{array}$ \\
\hline Sample F & $\begin{array}{l}\text { Base Mud }+5 \mathrm{~g} \mathrm{Na}_{2} \mathrm{CO}_{3}+3 \mathrm{~g} \mathrm{CaSO}_{4}+12 \mathrm{~g} \\
\text { Barite }\end{array}$ \\
\hline Sample G & Base mud $+1 \mathrm{~g} \mathrm{NaHCO}_{3}$ \\
\hline Sample H & Base mud $+3 \mathrm{~g} \mathrm{NaHCO}_{3}$ \\
\hline Sample K & Base mud $+5 \mathrm{~g} \mathrm{NaHCO}_{3}$ \\
\hline
\end{tabular}

\begin{tabular}{|c|l|}
\hline $\begin{array}{l}\text { Sample } \\
\text { Name }\end{array}$ & Mud treatment \\
\hline Sample L & $\begin{array}{l}\text { Base mud + } 1 \mathrm{~g} \mathrm{NaHCO}_{3}+0.3 \mathrm{~g} \mathrm{NaOH}+ \\
5 \mathrm{ml} \mathrm{H}_{2} \mathrm{O}\end{array}$ \\
\hline Sample $\mathrm{M}$ & $\begin{array}{l}\mathrm{Base} \mathrm{mud}+3 \mathrm{~g} \mathrm{NaHCO}_{3}+0.5 \mathrm{~g} \mathrm{NaOH}+ \\
7 \mathrm{ml} \mathrm{H}_{2} \mathrm{O}\end{array}$ \\
\hline Sample N & $\begin{array}{l}\mathrm{Base} \mathrm{mud}+5 \mathrm{~g} \mathrm{NaHCO}_{3}+0.8 \mathrm{~g} \mathrm{NaOH} \\
+10 \mathrm{ml} \mathrm{H}_{2} \mathrm{O}\end{array}$ \\
\hline
\end{tabular}

Figure 7 shows $\mathrm{pH}$ values of the base, contaminated and treated mud samples; the base mud sample $\mathrm{pH}$ of 9.88 as $\mathrm{pH}$ of contaminated mud samples $\mathrm{A}, \mathrm{B}$, and $\mathrm{C}$ decreased with the increase of contaminated concentration of sodium carbonate from 1 to $5 \mathrm{~g}$ until $\mathrm{pH}$ reached 8.5. In contrast, calcium sulphate was further added to act as an additive to reduce mud sample $\mathrm{pH}$. Results obtained in Figure 7 show that the $\mathrm{pH}$ value of mud samples D, E, and F dropped from 9.95 to 9.81 that slightly altered the base mud $\mathrm{pH}$.

On the other hand, as the mud samples $\mathrm{G}, \mathrm{H}$ and $\mathrm{K}$ were contaminated by sodium bicarbonate at concentrations varied from 1 to $5 \mathrm{~g}$, pH value gradually decreased from 8.88 to 8.66 compared to the base mud pH of 9.88 as seen in Figure 8. The contaminated mud was then treated by sodium hydroxide agent, which reacted as an additive to improve contaminated mud $\mathrm{pH}$. The addition of sodium hydroxide at different concentrations of $0.3,0.5$ and $0.8 \mathrm{~g}$ significantly increased $\mathrm{pH}$ value of the mud 
International Journal of Engineering Research and Technology. ISSN 0974-3154, Volume 13, Number 5 (2020), pp. 1019-1029

(C) International Research Publication House. https://dx.doi.org/10.37624/IJERT/13.5.2020.1019-1029

samples L, M, and $\mathrm{N}$ from 9.8 to 10.02 , which was closer to

base mud $\mathrm{pH}$ and satisfies its properties.

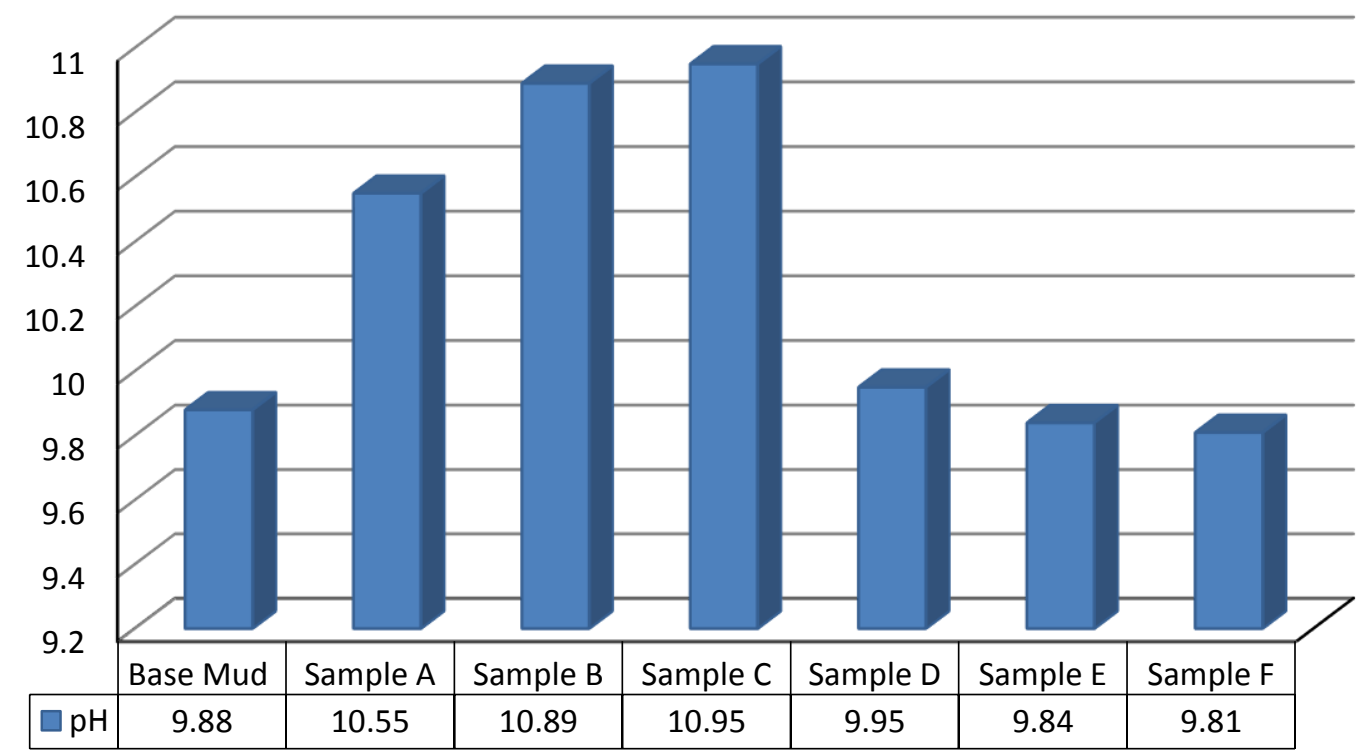

Figure 7: $\mathrm{pH}$ of contaminated and treated samples with sodium carbonate and calcium sulphate.

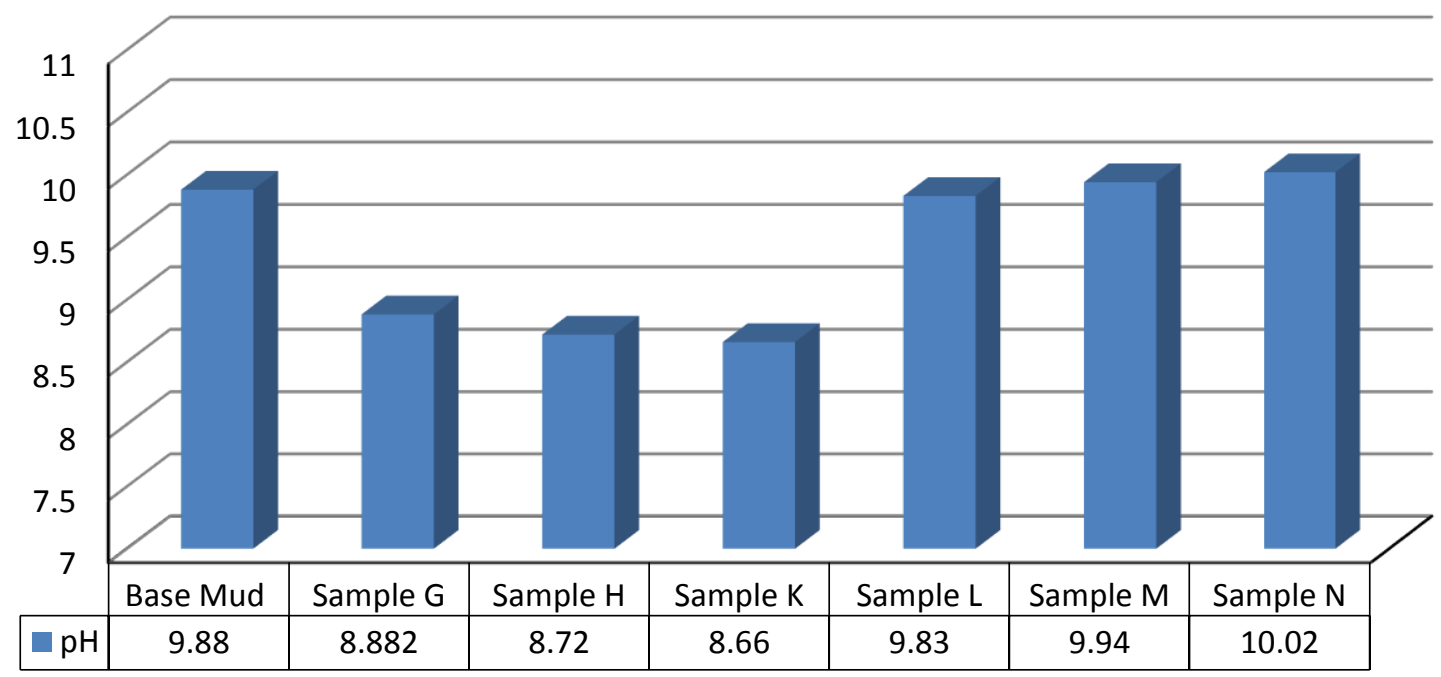

Figure 8: $\mathrm{pH}$ of contaminated and treated samples with sodium bicarbonate and sodium hydroxide.

\section{Plastic Viscosity}

Plastic Viscosity (PV) expresses the fluid resistance to flow due to mechanical friction. It is affected by a solid type, size and concentration in a given fluid and also the continuous phase viscosity. If solid content increases in the mud that maybe in the form of drill solids, barite, loss circulation material and many others, then the mud plastic viscosity increases [8]. PV was measured for both contaminated mud samples. Figure 9 shows plastic viscosity of sodium carbonate contaminated mud samples A, B, and C in which PV sharply increased to $5 \mathrm{cp}$ as $1 \mathrm{~g}$ of sodium carbonate material was added. Then PV decreased to $4 \mathrm{cp}$ as sodium carbonate concentration increased to $5 \mathrm{~g}$. However, the contaminated drilling mud was treated by calcium sulphate and mud samples D and E properties were modified until the original base mud PV was restored. As calcium sulphate concentration increased to $3 \mathrm{~g}$ in sample $\mathrm{F}$, PV slightly dropped below $3 \mathrm{cp}$. This behaviour is due to the treatment of sodium carbonate by calcium ion in which carbonate ions act as contaminants during the treatment.

In contrast, as mud samples $\mathrm{G}, \mathrm{H}$ and $\mathrm{K}$ were contaminated by $1 \mathrm{~g}$ sodium bicarbonate as shown in Figure 10, the PV remained unchanged from the base mud PV of $3.5 \mathrm{cp}$. However, as sodium bicarbonate concentration increased to 3 and $5 \mathrm{~g}$, respectively, the PV instantly declined and remained steady at 3 cp. Contaminated samples L, M and $\mathrm{N}$ were treated by sodium hydroxide, therefore, the PV was restored to original property of base mud reaching $3.5 \mathrm{cp}$. However, adding extra 
sodium hydroxide concentrations of 3 and $5 \mathrm{~g}$, the PV gradually increased to $4 \mathrm{cp}$, i.e. higher than the base mud PV.

\section{Yield Point}

The yield point (YP) is the resistance to initial flow of drilling mud. YP is influenced by mud solids surface properties and solids volume concentration and type and concentration of ions in the mud fluid. Figure 11 shows the YP of sodium carbonate contaminated drilling fluids. Contamination concentration increased in mud samples A and B leading to sharp increase in YP of $23 \mathrm{lb} / 100 \mathrm{ft}^{2}$. The regular increase in YP is due to the attractive force between the cement colloidal particles and the clay (bentonite) particles. Moreover, the cement bonding ability improved the overall fluid bonding. It was reported that a sudden increase in $\mathrm{pH}$ leads to rise in contaminated mud YP [9]. Further addition of drilling mud contaminant at higher concentration of $5 \mathrm{~g}$ in sample $\mathrm{C}$ caused decline in $\mathrm{YP}$ to 20 $\mathrm{lb} / 100 \mathrm{ft}^{2}$. The contaminated drilling mud samples D, E and F were treated by different concentrations of calcium sulphate. The addition of various concentrations of treating agent led to sharp decrease in YP to lowest value of $5 \mathrm{lb} / 100 \mathrm{ft}^{2}$ that is similar to the original WBM YP.

Figure 11 shows drilling mud samples G, H, K, L, M and N that were contaminated and treated by sodium bicarbonate and sodium hydroxide. The YP, from the figure, has a similar trend to those samples contaminated by sodium carbonate. The YP has a maximum value at a concentration of $1 \mathrm{~g}$ and decreased to $7 \mathrm{lb} / 100 \mathrm{ft}^{2}$ as contaminant concentration increased to $5 \mathrm{~g}$. This indicates that there is strong attraction between the charged material particles which is consistent with previous observations [8, 10 and 11]. Furthermore, the YP significantly decreased as contaminated mud samples $\mathrm{L}, \mathrm{M}$ and $\mathrm{N}$ were treated by sodium hydroxide. The YP declined from 7 to 4.5 $\mathrm{lb} / 100 \mathrm{ft}^{2}$ at sodium hydroxide concentration of $1 \mathrm{~g}$ and continued to decline as an additional treating agent was added until reaching the lowest value of $3.5 \mathrm{lb} / 100 \mathrm{ft}^{2}$, which is close to the original MBW YP of $3 \mathrm{lb} / 100 \mathrm{ft}^{2}$.

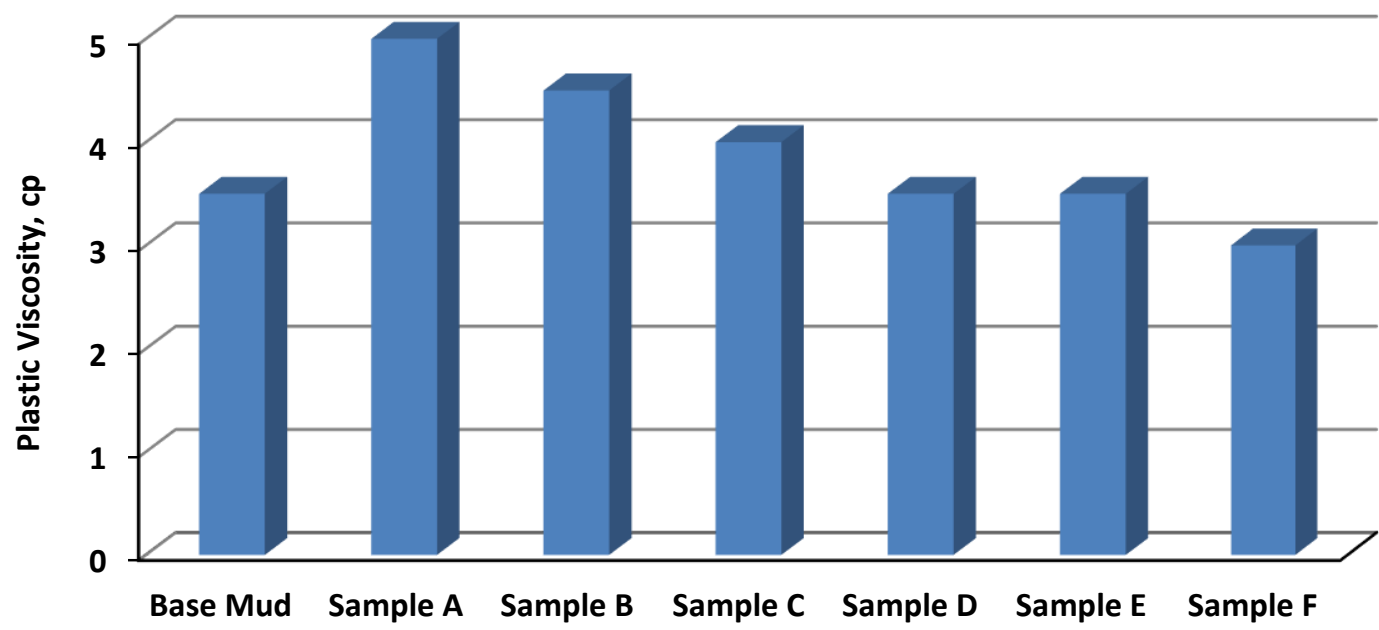

Figure 9: PV of contaminated and treated samples by sodium carbonate and calcium sulphate.

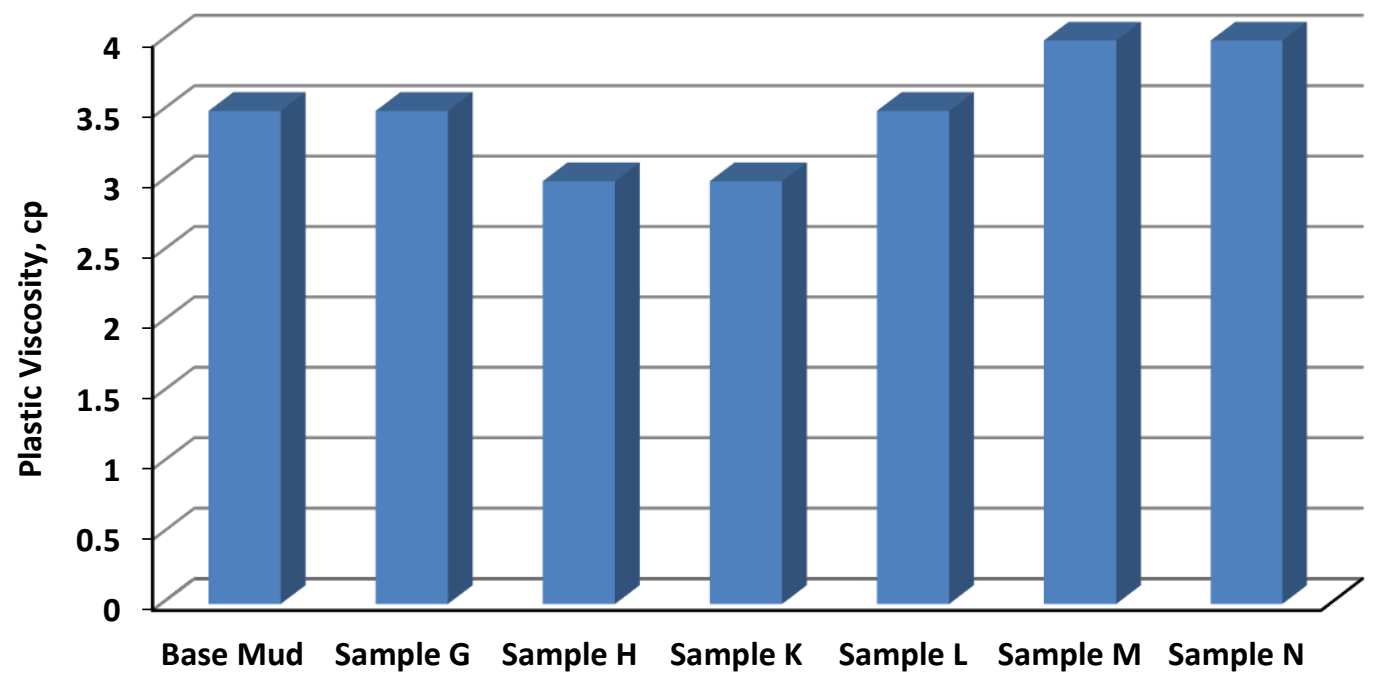

Figure 10: PV of contaminated and treated samples by bicarbonate and sodium hydroxide. 


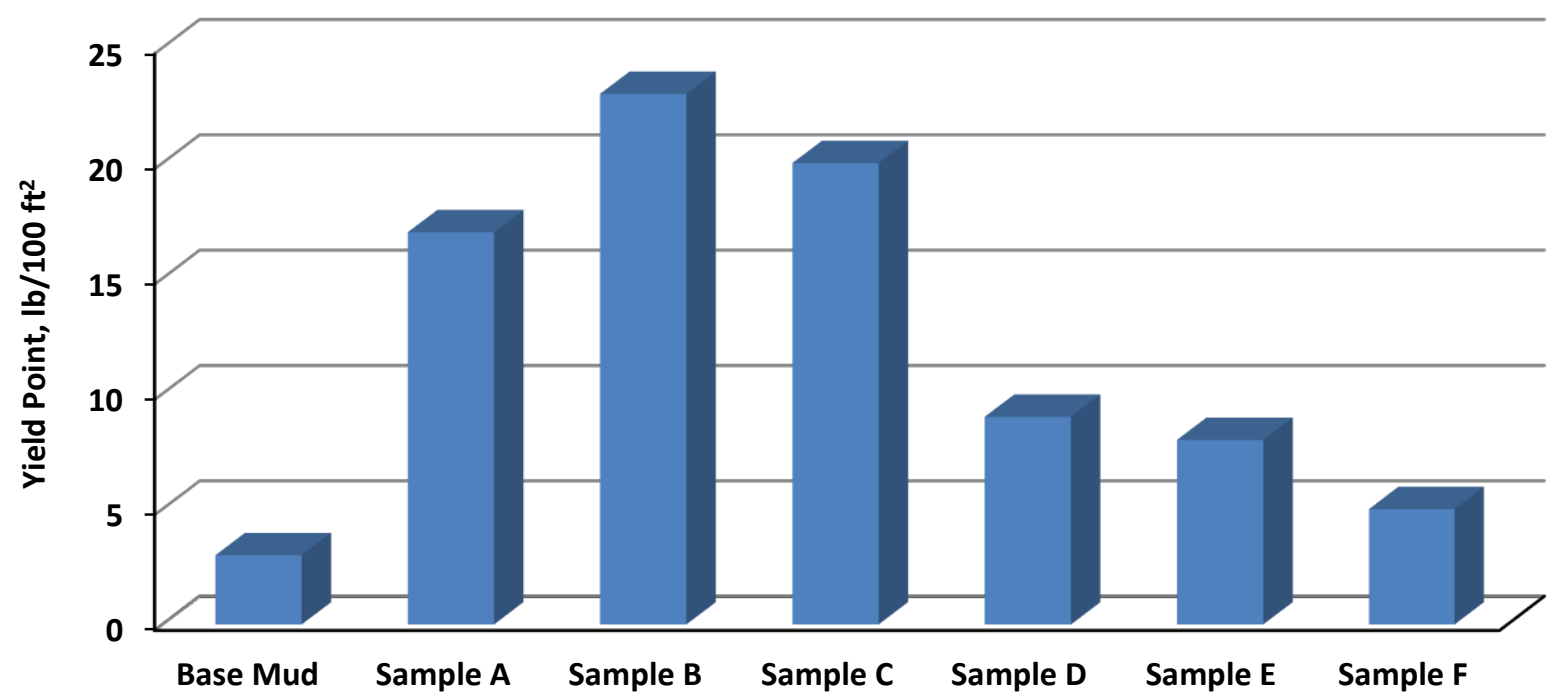

Figure 11: YP of WBM at different sodium carbonate and treating agent concentrations.

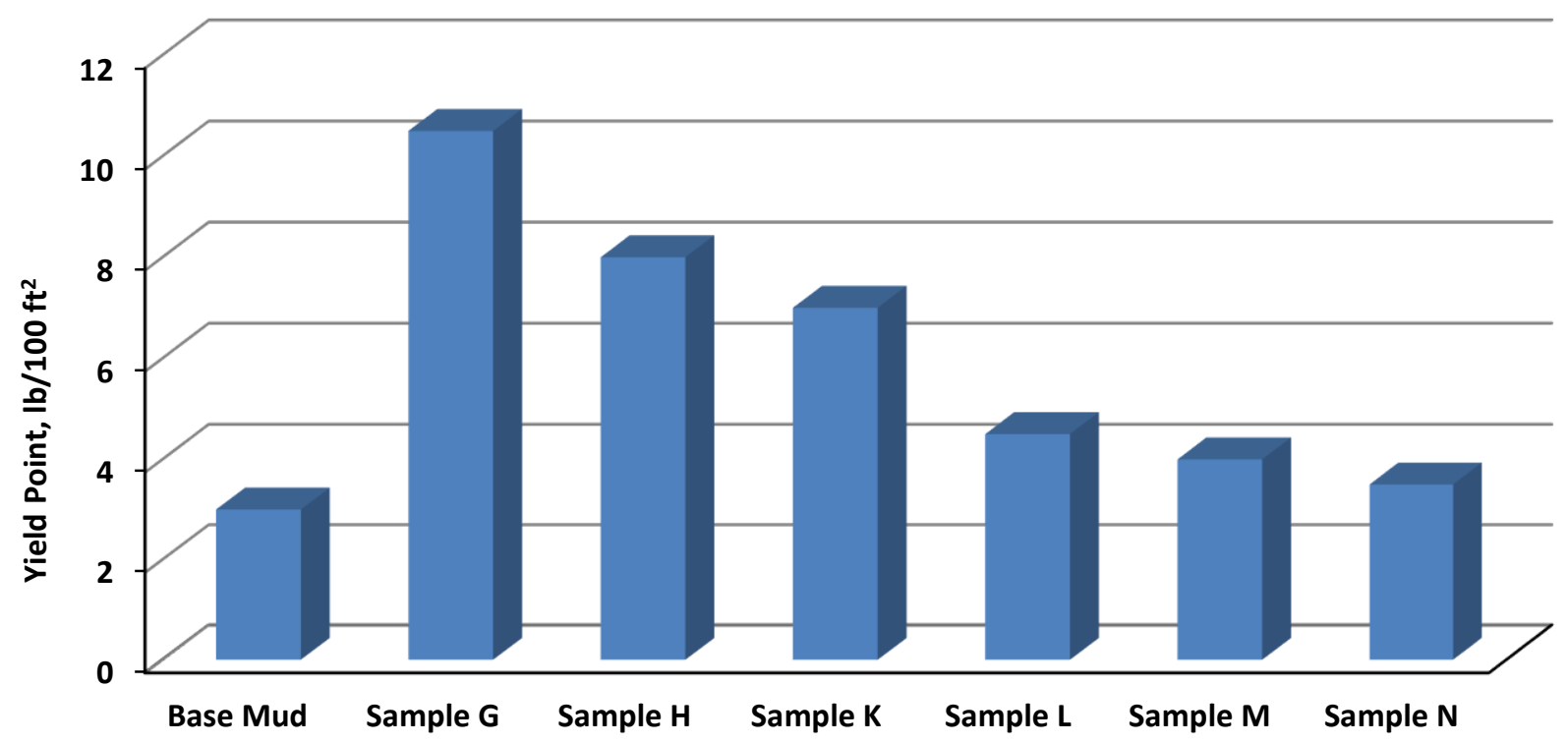

Figure 12: YP of WBM at different sodium bicarbonate and treating agent concentrations.

\section{Gel Strength}

Gel strength (GS) is a measurement of electrochemical forces in the mud fluid under static conditions. The results obtained for GS at 10 seconds and 10 minutes of drilling fluid mud at different concentrations, contaminations and treating agents are shown in Figures 13 and 14, respectively. When the mud is at static situation, the strength of any internal structure formed constitutes the developed mud GS. It shows the pressure required to initiate flow after the mud has been static [12]. This feature helps drilling mud remove suspended cuttings along the drill-pipe and/or borehole annulus as the drilling mud circulates during tripping or any other operations [13]. Figure 13 shows that the GS at 10 seconds and 10 minutes increased significantly in sample A and B as the contaminant and treating agent concentrations increased. This is due to the cement bonding tendency and $\mathrm{pH}$ increase [9]. Considering the GS at 10 seconds and 10 minutes at ambient temperature of $25^{\circ} \mathrm{C}$, uncontaminated WBM set was $4 \mathrm{lb} / 100 \mathrm{ft}^{2}$ at 10 seconds and $14 \mathrm{lb} / 100 \mathrm{ft}^{2}$ at 10 minutes. These value increased suddenly to $19 \mathrm{lb} / 100 \mathrm{ft}^{2}$ at 10 seconds and $36 \mathrm{lb} / 100 \mathrm{ft}^{2}$ at 10 minutes for sample A; $24 \mathrm{lb} / 100 \mathrm{ft}^{2}$ at 10 seconds and $41 \mathrm{lb} / 100 \mathrm{ft}^{2}$ at 10 minutes for sample B. Then it declined to $21 \mathrm{lb} / 100 \mathrm{ft}^{2}$ at 10 seconds and $27 \mathrm{lb} / 100 \mathrm{ft}^{2}$ at 10 minutes for sample C. Similar trends were observed for GS at 10 seconds and 10 minutes for treating agent samples D, E, and F. High GS may cause several problems during drilling operation as bit balling, pipe sticking and difficulty in running logging instruments downhole. 
International Journal of Engineering Research and Technology. ISSN 0974-3154, Volume 13, Number 5 (2020), pp. 1019-1029

(C) International Research Publication House. https://dx.doi.org/10.37624/IJERT/13.5.2020.1019-1029

Figure 14 shows that adding sodium bicarbonate increased the mud GS at seconds to $8 \mathrm{lb} / 100 \mathrm{ft}^{2}$ and decreased the GS to 9 $\mathrm{lb} / 100 \mathrm{ft}^{2}$ at 10 minutes for sample G. Then the GS gradually decreased at samples $\mathrm{H}$ and $\mathrm{K}$. A similar trend for GS at 10 seconds and 10 minutes by adding the treating agent sodium hydroxide in samples $\mathrm{L}, \mathrm{M}$, and $\mathrm{N}$. The maximum GS recorded were 9 and $17 \mathrm{lb} / 100 \mathrm{ft}^{2}$ at 10 second and 10 for sample then gradually declined in samples $\mathrm{M}$ and N. Sample N maintained the same GS of $14 \mathrm{lb} / 100 \mathrm{ft}^{2}$ at 10 minutes as WBM.

\section{Fluid Loss}

Figures 15 and 16 show the fluid loss results at different contaminants concentrations at $25^{\circ} \mathrm{C}$ temperature. Figure 15 shows the fluid loss increased with increasing sodium carbonate concentrations up to a maximum value of $23 \mathrm{ml}$. The effect of increasing sodium carbonate concentrations was not clearly observed at 1 and $3 \mathrm{~g}$. The same trend was observed in Figure 16 for fluid loss at various concentrations of sodium bicarbonate, however, higher fluid loss values of $30 \mathrm{ml}$ were reached. This increase in fluid loss could be due to flocculation of fresh water bentonite systems by cement, which is affected by rising mud system $\mathrm{pH}[9]$.

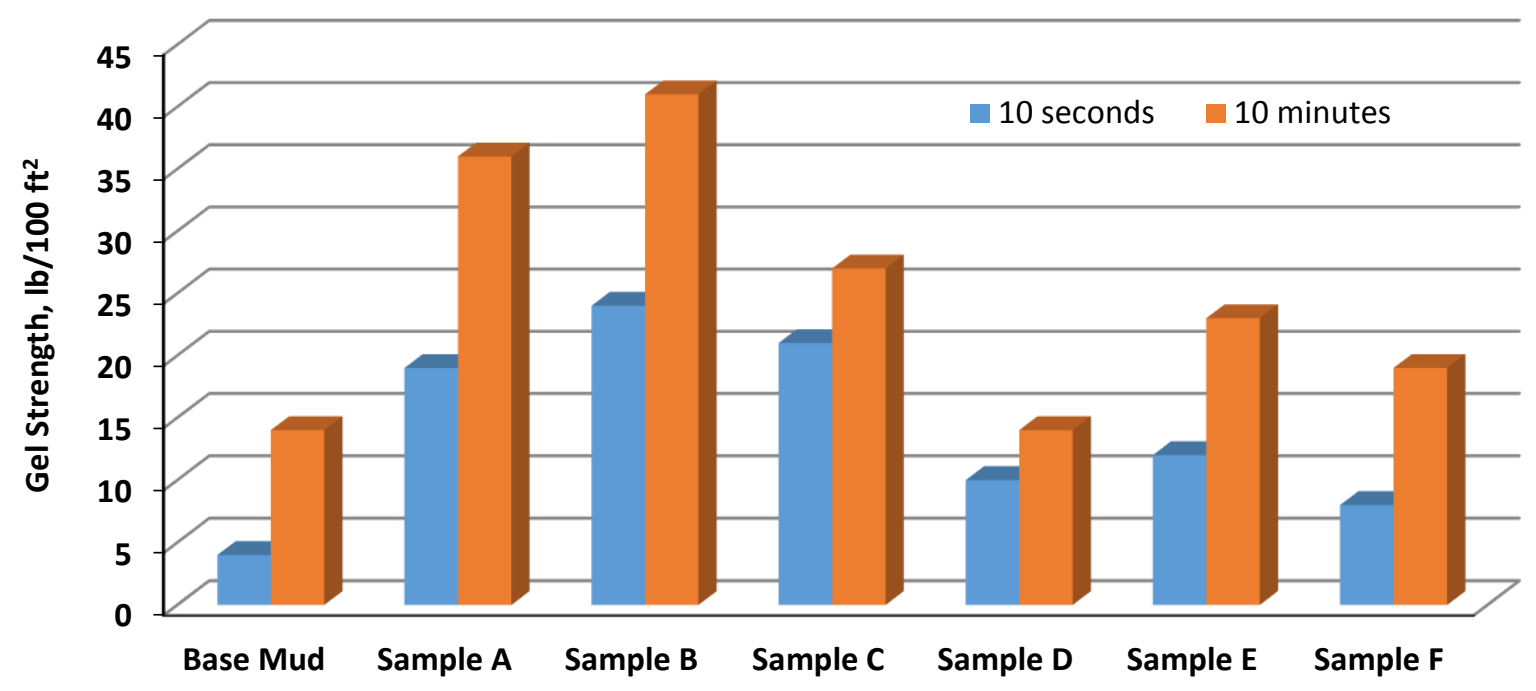

Figure 13: GS of fluid mud at different sodium carbonate and calcium sulphate concentrations at different time

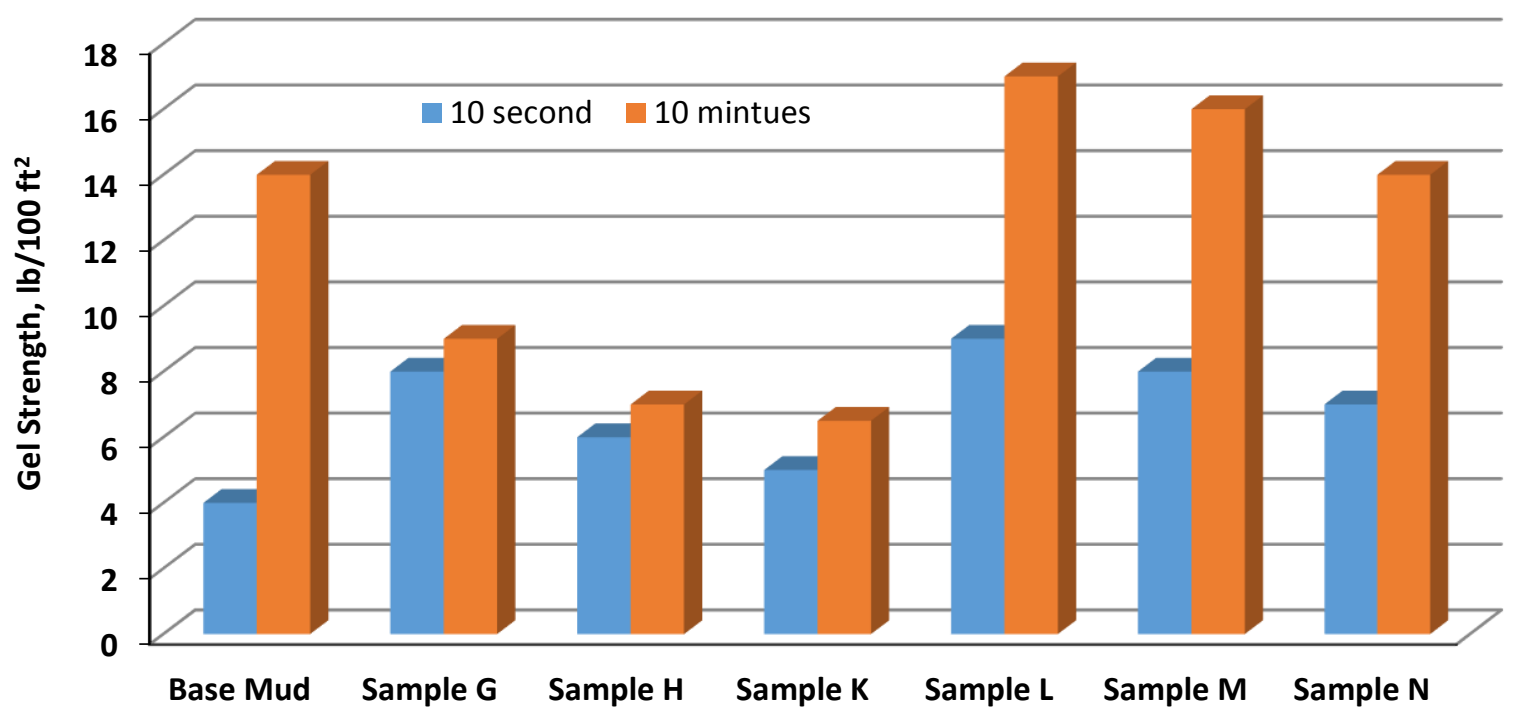

Figure 14: GS of fluid mud at different sodium bicarbonate and sodium hydroxide concentrations at different time. 


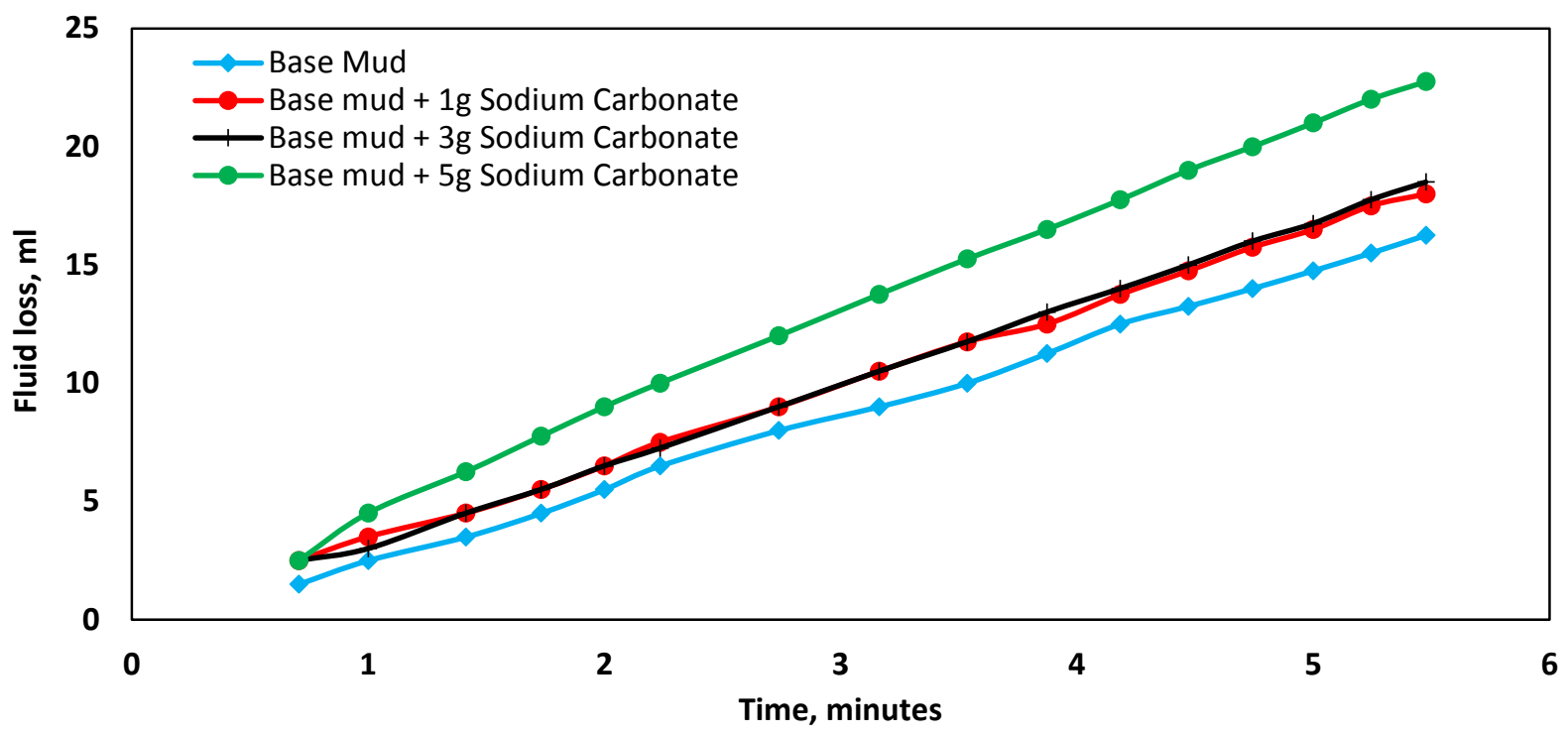

Figure 15: Fluid loss of base mud at different sodium carbonate concentrations.

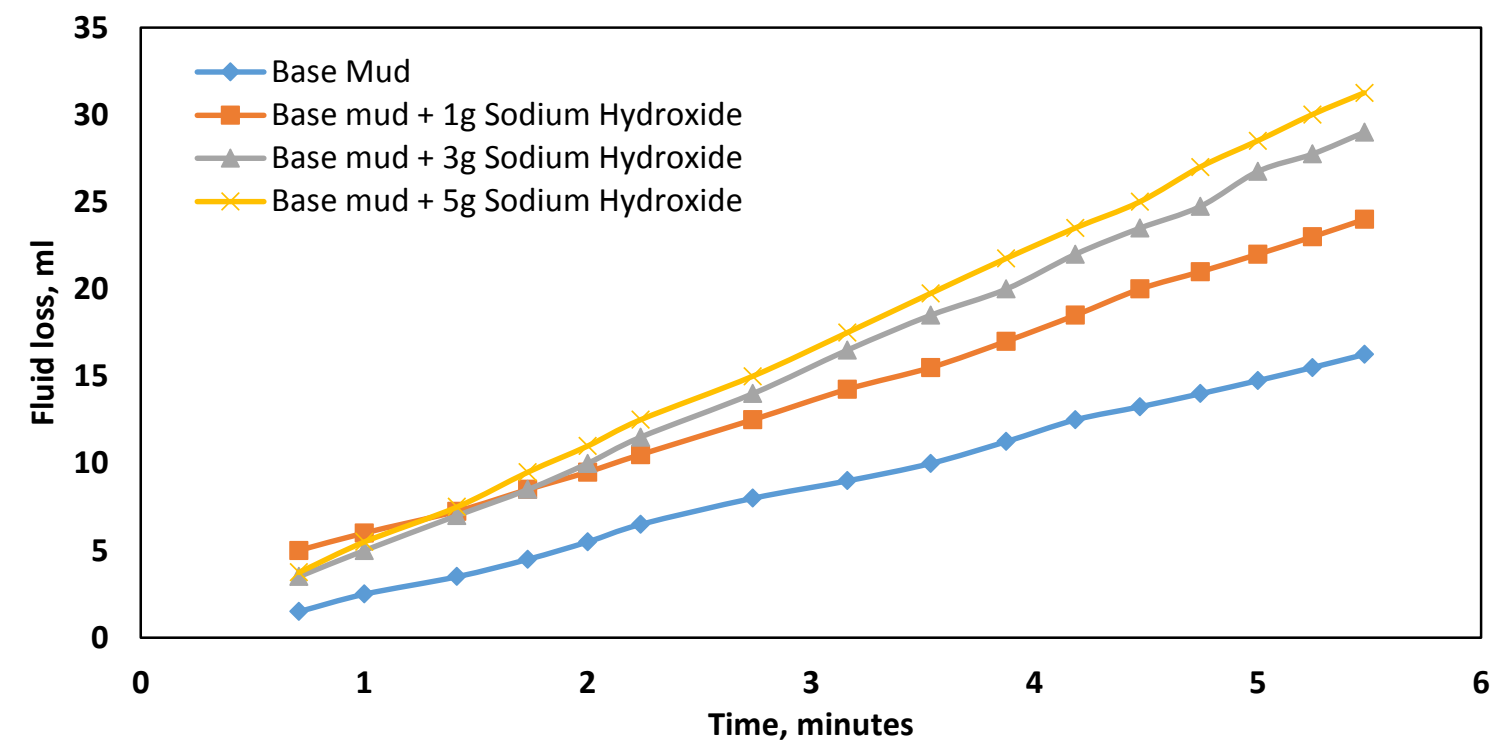

Figure 16: Fluid loss of base mud at different sodium carbonate concentrations.

\section{CONCLUSIONS AND RECOMMENDATION}

This study investigated the effect of two cement contamination components, namely sodium carbonate and sodium bicarbonate, on WBM physical properties. Different concentrations of 1,3 and $5 \mathrm{~g}$ of contaminants and treating agent were added to the mud system. The following conclusions can be made:

- Mud thickness increased as the contaminants concentrations increased.

- $\quad$ Mud $\mathrm{pH}$ increased as the concentration of sodium carbonate contamination increased but it decreased as sodium bicarbonate concentration increased. Treating agents nearly restored the developed mud system original $\mathrm{pH}$.
- Plastic viscosity decreased gradually as concentration of contamination and treating agent increased but slightly increased with the increase of sodium hydroxide concentration.

- Yield point increased sharply as contaminants concentration increased. However, yield point decreased gradually as the mud became contaminated by high concentration of sodium carbonate and sodium bicarbonate.

- Gel strength behaves differently at 10 second than at 10 minutes. It increased gradually as concentration of sodium carbonate and calcium sulphate increased but decreased when concentration increased to $5 \mathrm{~g}$. The 
same trend was observed for sodium bicarbonate and sodium hydroxide.

- Fluid loss increased as cement concentrations increased at $25^{\circ} \mathrm{C}$ because of the flocculation of fresh water bentonite systems in the cement.

We recommend undertaking the experiments of the current work at elevated temperature and pressure conditions similar to those encountered in the wellbore while drilling deep oil or gas wells to observer whether the same results and trends can be reproduced or not.

\section{REFERENCES}

[1] Olufemi. A. Adekomaya, Olalekan Olafuyi (2011). An experimental study of the effect of contaminants on the flow properties of oil based drilling mud. Journal of Petroleum \& Coal 53(4) 315-319.

[2] Kassim. M. (2016). Experimental Investigation of the Effects of Contaminants on the Rheological Properties of Water-based Mud. Bachelor Thesis, Federal University of Petroleum Resources, Delta State, Nigeria.

[3] Akpabio, J. U., Inyang, P. N. and Iheaka, C. I. (2015). The Effect of Drilling Mud Density on Penetration Rate. International Research Journal of Engineering and Technology, Vol. 2 (9).

[4] Awele, N. (2014). Investigation of Additives on Drilling Mud Performance with "TØNDER GEOTHERMAL DRILLING" AS A CASE STUDY. Master Thesis, Aalborg University Esbjerg.

[5] Ismail, A. R. and Meng, K. (2000). The Effects of Contamination on Plastic Viscosity. Malaysian Science and Technology Congress, Kota Kinabalu, Sabah, 18 - 20 September 2000.

[6] Bahand, S., Ghabezloo, S., Duc, M., et al. Effect of the hydration temperature on the microstructure of Class $\mathrm{G}$ cements: C-S-H composition and density. Cement Concrete Res. 2017, 95(3): 270-281.

[7] Mohamadian, N., Ghorbani, H., and Wood, D. (2018). Rheological and Filtration Characteristics of Drilling Fluids Enhanced by Nanoparticles with Selected Additives: An Experimental Study. Adv. Geo-Energ. Res., 2(3): 228-236

[8] Dankwa, O.K., Appau, O.P., and Broni-Bediako, E. (2018). Evaluating the Effects of Monovalent and Divalent Salts on the Rheological Properties of Waterbased Mud. Open Petrol. Eng. J., 11(1): 98-106.

[9] Annis, M.R., and Smith, M.V. (1996). Drilling Fluid Technology, Exxon Company, U.S.A.

[10] Abduo, M.I., Dahab, A.S., Abuseda, H., et al. (2016). Comparative Study of Using Water-based Mud Containing Multiwall Carbon Nanotubes versus Oilbased Mud in HPHT Fields. Egypt. J. Petrol., 25: 459464.
[11] Yunita, P., Irawan, S., and Kania, D. (2016). Optimization of Water-based Drilling Fluid Using Nonionic and Anionic Surfactant Additives. Procedia Eng., 148: 1184-1190.

[12] Amorin, R. (2016). Drilling Fluids. Unpublished BSc Lecture Notes, University of Mines and Technology, Tarkwa.

[13] Shah, S.N., Shanker, N.H., and Ogugbue, C.C. (2010). Future Challenges of Drilling Fluids and their Rheological Measurements. AADE Fluids Conference and Exhibition, Hilton Houston North, Houston, Texas, 6-7 April. 